\title{
César Dávila Andrade: la sorprendente ambivalencia de su mirada. Narrar lo incorpóreo, la pavorosa intimidad humana y la imperecedera ternura*
}

César Dávila Andrade: the surprising ambivalence of his gaze. Narrate the incorporeal, the terrifying human intimacy and the everlasting tenderness

\author{
Alicia Ortega Caicedo** \\ Universidad Andina Simón Bolívar, Sede Ecuador \\ alicia.ortega@uasb.edu.ec \\ https://doi.org/10.32719/13900102.2018.43.2 \\ Fecha de recepción: 16 febrero 2018 \\ Fecha de aceptación: 19 abril 2018
}

\section{RESUMEN}

Este escrito es un testimonio de lectura, un regreso al Fakir, un homenaje a César Dávila Andrade en la celebración del centenario de su nacimiento. La autora vuelve a leer algunos de sus cuentos y escritos de prosa no ficcional, cartas suyas, novelas y semblanzas que algunos de sus contemporáneos escribieron sobre él o lo convirtieron, años más tarde otros, en personaje de novelas. Lo que me interesa es comprender cómo miró, sé miró y fue mirado, porque sobre la mirada del escritor quiero reflexionar.

PALABRAS CLAVE: Ecuador, César Dávila Andrade, cuento, literatura, mirada, escritura.

* Este texto fue leído en una mesa de homenaje al centenario del nacimiento de César Dávila Andrade, en la II Feria del Libro Independiente de la Universidad San Francisco de Quito (2-4 de octubre de 2018, Campus USFQ). ( $\mathrm{N}$ de la A).

** Ecuatoriana. Docente titular en la Universidad Andina Simón Bolívar, Sede Ecuador, en el Área de Letras y Estudios Culturales. Magister en Letras por la Universidad Andina Simón Bolívar y Ph. D. en Literatura Latinoamericana por la Universidad de Pittsburgh. La tradición narrativa ecuatoriana, la novela contemporánea escrita por mujeres en América Latina, la ciudad y sus representaciones literarias, la historia de la crítica literaria latinoamericana focalizan sus intereses académicos. Forma parte del comité editorial de la revista en línea Sycorax (http:/l proyectosycorax.com). Últimas publicaciones: Fuga hacia dentro. La novela ecuatoriana en el siglo XX (2017), Pensamiento crítico-literario de Alejandro Moreano (editora, 2014), Tradición marxista, cultura y memoria literaria: Agustín Cueva, Bolívar Echeverría y Alejandro Moreano (editora, 2014), Jorge Icaza y Pablo Palacio: vanguardia y modernidad (editora y coautora, 2013), Historia de las Literaturas del Ecuador, tomos 7 y 8 (editora y coautora, 2011). 


\section{ABSTRACT}

This writing is a testimony of reading, a return to the Fakir, a tribute to César Dávila Andrade in the celebration of the centenary of his birth. The author re-reads some of his stories, non-fictional prose writings, letters, novels and sketches that some of his contemporaries wrote about him or converted, years later, into a novel character. What interests me is to understand how he himself looked, he looked at others and was looked at, because it is on the writer's gaze that this seeks to reflect.

KEYWORDS: Ecuador, César Dávila Andrade, short story, literature, gaze, writing.

\section{Figuraciones literarias}

Muy al inicio de la novela de Jorge Enrique Adoum, Entre Marx y una mujer desnuda (1976), reconocemos una explícita referencia al Fakir, entre paréntesis y en el marco de una reflexión acerca de la escritura, la provocación de la página en blanco, la pregunta por el oficio de escritor, el lugar de la pasión y los afectos en el "combate" con la palabra:

(Cuando obligado por Gálvez, el Fakir se resignó a ir al hospital por una inflamación de la pleura que venía tratándose desde hacía algunas semanas con quemados de aguardiente, uno de los empleados al inscribirlo, le preguntó su profesión. Poeta, dijo naturalmente orgullosamente porque esa fue su única ocupación en la tierra. No es eso lo que le pregunto, dijo el empleado, sino en qué trabaja. En la poesía, dijo el Fakir. Otro empleado, el inteligente, dijo a su colega: Pon periodista nomás. Lo peor hermanito, contaba el Faquir, fue cuando el domingo de mañana pregunté si podían darme comprando el periódico. Por qué no lee más bien el de ayer que tenemos, me dijo el interno. Porque hoy me iban a publicar un poema, le dije, por lo menos el Llerenita me lo ofreció. Cuando pasó el médico, porque de veras pasó de largo por las camas de los enfermos sin mirarlos siquiera, el interno le dijo señalándome por sobre el hombro, como si le indicara Accidente de tránsito o 39 de temperatura: delirio de grandeza) (Adoum 1986, 11-12).

Una de las imágenes que con más fuerza ronda el imaginario literario ecuatoriano acerca del Fakir coincide con la idea del escritor maldito: alcoholizado, trashumante en su deambular nocturno, inconforme y extraño en un medio provinciano: "Dávila era un ser próximo de sus personajes atormentados, en muchos sentidos; y en esas noches de interminable bebida, en las que perdía no solo el sentido de la realidad, sino todo, hasta la ropa que cubría su cuerpo y el poco dinero que le pagaban por la corrección de pruebas en la imprenta de la Casa de la Cultura, lo que hacía era peregrinar en pos de sí mismo y del verdadero sentido de la existencia, a tientas, en medio de las tinieblas del alcohol y la miseria, entre aquellos a los que consideró siempre sus hermanos, con una ternura digna de los santos (Dávila Vázquez 2005). De hecho, una de 
las últimas imágenes que conservaba yo del escritor era su presencia como personaje de Eliécer Cárdenas, en El pinar de Segismundo (2008): una novela que, en palabras de su autor, "fue escrita cuando se conmemoraba en Ecuador el centenario del nacimiento de Jorge Icaza e iba a cumplirse el cincuentenario de la tardía aparición de la novela Égloga trágica de Gonzalo Zaldumbide." (Cárdenas 2008, 167). Efectivamente, Icaza y Zaldumbide entran en la novela de Cárdenas junto con otros escritores y artistas que protagonizaron el medio literario durante la primera mitad del siglo pasado: César Dávila, G. H. Mata, Oswaldo Guayasamín, entre otros; “amigos y cofrades" vinculados a la Casa de la Cultura bajo el liderazgo de Benjamín Carrión. Los personajes, sujetos históricos reales, son retratados en la novela de Cárdenas en su dimensión más cotidiana: pasiones personales, pequeñas venganzas y rivalidades, complicidades y búsquedas, en el desarrollo de una lograda trama que porta las huellas de otros textos -escondidos y asimilados- a manera de una sobre-determinación intertextual (Boletín y elegía de las mitas, El Chulla Romero y Flores, como ejemplos). En el presente narrativo, 1956, Icaza, Mata, Dávila Andrade, Guayasamín, son convocados en la biblioteca de la casa de Benjamín Carrión, por su secretario privado. Los confabulados deben cumplir una secreta misión, que consiste en robar los manuscritos dispersos y ocultos de Égloga trágica, con el fin de minar la salud emocional de Zaldumbide e impedir su candidatura como binomio de Camilo Ponce en las próximas elecciones. Lo que me interesa ahora destacar de esa lectura es la presencia de César Dávila en el relato: su consistencia humana, su trazo y guiños biográficos, las resonancias de ese nombre propio en la escritura:

Delgado, de aspecto frágil, unos ojos inquietos emboscados tras lentes gruesos de montura, asomó por la puerta de la biblioteca el poeta César (Cárdenas 2008, 18).

¿Y qué podemos hacer nosotros? -sonó la voz de cristal mellado del poeta César, como un amortiguado trino después de la tempestad de las palabras de Grijalva. Junto a Guayasamín, su figura semejaba el desvalimiento humano y corporal ante la estridencia de un ser pletórico de vida (21).

Su aliento olía a licor barato, y por lo ajado de su traje, la corbata con el nudo maltrecho, podía colegirse que se había pasado la noche de cantina en cantina en aquel centro de la capital tan pródigo en tabernuchas y guaraperías ínfimas (55).

Prima en la imaginación fabuladora que recrea al poeta su "errático peregrinaje por las más infelices tabernas", su deambular ritual "reconocido y abrazado por borrachos de mala traza". En la novela de Cárdenas, Dávila Andrade aparece como un personaje de ojos tristes y tímidos, de gestos 
nerviosos y de pocas palabras. En el curso de la fábula, el poeta delega en otro el cumplimiento de la misión asignada, mientras se refugia en una cantina cualquiera del sector quiteño La Marín. Escribe sin parar en cualquier servilleta o pedazo de papel, como si la escritura se tratara de una urgencia siempre impostergable. Sin duda, se trata de una novela ingeniosa, que incorpora el nombre propio de varios personajes reales como tributo y homenaje lleno de afecto. La operación de nominación de los personajes, en función de un referente literario real, teje una escritura que nos seduce por efecto de una especial familiaridad que la sola mención de los nombres hace posible. El solo reconocimiento provoca en el lector un particular placer, porque todo un acumulado de conocimiento se activa ante la enunciación del nombre propio. Cabe entonces preguntarnos qué conocimiento se activa cuando de César Dávila Andrade se trata. Más aún, cuando la leyenda, los episodios biográficos, el imaginario, la sombra del suicidio nos convocan.

Antes de pasar a la lectura de algunas de sus cartas y cuentos, resulta oportuno leer una parte de la breve noticia biográfica que le dedica María Augusta Vintimilla en el contexto de una reflexión acerca de la poesía daviliana:

César Dávila Andrade (Cuenca 1928-Caracas 1967) llevó una existencia azarosa y atormentada, signada por una aguda conciencia de descentramiento y exilio, y por una no menos angustiada búsqueda de afirmación existencial a través de una poesía intensa, extraña y poderosa que en sus exploraciones más extensas bordea el abismo del silencio. Su incesante peregrinaje por algunas ciudades del Ecuador y Venezuela concluyó abruptamente en un hotel de Carcas, en 1967; podemos conjeturar su soledad, las derrotas existenciales, las sucesivas crisis personales provocadas por el alcohol; pero sobre todo la terrible e íntima certeza de que la aventura poética que emprendió desembocaba en la aniquilación final del sentido, y quizás precipitó su decisión de seccionarse la garganta con una hoja de afeitar.

Dávila asumió la escritura como una audaz tentativa de alcanzar el conocimiento absoluto, la iluminación total, la imposible disolución de las fronteras que separan las palabras del sentido, el instante de fulguración en que el Buscador y lo Buscado se confunde $[\ldots]$ (Vintimilla 2012, 212). ${ }^{1}$

1. La producción narrativa de César Dávila Andrade se compone de varios relatos, algunos de los cuales fueron publicados en formato de libro -Abandonados de la tierra (1952), Trece relatos (1955) y Cabeza de gallo (1966)- y otros aparecieron en revistas y antologías. Sus relatos fueron recogidos en el segundo tomo de las Obras completas (Cuenca: Pontificia Universidad Católica del Ecuador/Banco Central del Ecuador, 1984), ambos tomos editados por Jorge Dávila Vázquez. Este segundo tomo, Relato, incluye también una significativa selección de ensayos, prosa poética y comentarios bibliográficos. Se trata de textos cortos, escritos en su momento para revistas y periódicos, principalmente para la revista venezolana Zona Franca de la que César Dávila fue un cercano colaborador. 


\section{Cartas: la conciencia vigilante de "un modesto soldado"}

Sin desconocer los episodios de una biografía atravesada por la nocturnidad y cierto desvalimiento, vale también advertir una forma de radicalidad y de fortaleza vital que ancla y se sostiene en la escritura: saberse poeta, responder desde la poesía cuando es interrogado acerca de su oficio, preguntar una y otra vez por la publicación de sus escritos (como evidencian sus cartas recogidas en publicaciones posteriores). En las cartas dirigidas a Benjamín Carrión, desde Caracas a inicios de los años cincuenta, el poeta le informa acerca de sus trabajos -en una agencia de publicidad venezolana, en los diarios El Nacional y La Esfera, así como en la radio- a la vez que solicita al reconocido crítico alguna "misión o tarea" para difundir publicaciones ecuatorianas de actualidad, así como también auspicio institucional y apadrinamiento para la publicación de su obra:

\footnotetext{
Cierta vez, en la oficina del novelista Alfredo Pareja, me había dicho usted que si la comodidad iba a entorpecer mi creación, prefería verme envuelto en constante lucha de dolores, para que escribiera. Bueno, en mi actual situación, de serenidad laboriosa, aunque no de holgura, he escrito dos libros de cuentos [se refiere a Abandonados de la tierra y Trece relatos], uno de los cuales se encuentra en poder del jurado del Concurso auspiciado por la Casa de la Cultura de Guayaquil; y un libro de poesía titulado Hombre total [libro que apareció bajo el título Catedral salvaje]. Como usted ve querido doctor Benjamín, no me han distraído de mi misión las algarabías que se alzan al borde del Mar Caribe (Dávila Andrade en Salazar 2012, 43-44).
}

En ese bregar por obtener auspicios para la publicación de sus libros, Dávila Andrade explícitamente deja entrever el imparable trabajo de una "conciencia vigilante" (así lo dice en la misma carta, en sus líneas finales). Una conciencia que, así la percibo, encarna un modo de escribir, de mirar, de habitar. Paso a la lectura de otra carta, que hace parte del Cuaderno preparado por Gustavo Salazar y publicado en 2012, esta vez dirigida a su cercano amigo Galo René Pérez. La carta, escrita desde Caracas y con fecha 16 de julio de 1951, sorprende desde su encabezado: "Señor licenciado/ Galo René Pérez Cruz/ Quito (la ciudad más bella del mundo)". El modo como califica a Quito, "la ciudad más bella del mundo", habla de esa perspectiva afectiva que provee la distancia geográfica, la conciencia de extranjeridad. Coincide con la lectura que el mismo Dávila hace del poemario de Carrera Andrade, Lugar de origen, en su célebre ensayo "Teoría del titán contemplativo". Allí, justamente nuestro escritor confiesa que la lectura de ese poema lo devuelve a su propio lugar de origen, en donde prefiere ver el cielo y definirlo como "un estado del alma”, reconocer en las llanuras inmensurables la huella de las 
manos con las que Dios las alisa "como después de un gran cansancio". Vuelvo a la carta:

\begin{abstract}
Hace mucho que esperaba una hora para escribirte con calma. [...] Por mi parte, sé decirte que he vivido y luchado. No pude dar el salto del Atlántico, porque cuando yo llegaba a Panamá, los delegados del Congreso madrileño retornaban, con placer mío. En esa coyuntura resolví seguir la ruta de los viejos piratas caribes, y así recorrí el Mar de las Antillas, saltando de isla en isla, en su periplo inolvidable. Finalmente de la isla Margarita salté a Venezuela y entré en el dédalo de cemento e inmigrantes que es Caracas. Ciudad violenta, a esta hora, llena de los más inverosímiles contrastes de riqueza y desequilibrio pero centro de una gran experiencia humana, que es lo principal para un modesto soldado que quiere conocer la vida en lo más denso de las batallas sin historia.

Aquí me tienes, ya residente en este país extraordinario, perdido en una de las mil urbanizaciones en que la ciudad prolifera, unido a la vida humana más que nunca por el tintero y por el corazón. He trabajado en muchas cosas prácticas y tremendas; me he improvisado con alegría, en otras, y he escrito algo, cada día (Dávila Andrade en Salazar 2012, 51-52).
\end{abstract}

Esas cartas de los primeros años en Caracas están impregnadas de una fuerza que le genera un distanciamiento con su propia "sombra ciudadana": "Desde lejos, se ama el Ecuador con un celo profundo, y tal vez, puro de todo mal interés, de toda cáscara, de todo rencor" (Dávila Andrade en Salazar 2012, 54). Todas las cartas que han sido recogidas están cargadas de afecto para sus amigos del lado de acá, quienes no dejaron de pergeñar semblanzas y retratos del Fakir alrededor de una memoria compartida, afectiva y literaria. De las anécdotas recogidas, me interesa destacar aquellas que referidas a "la miopía de César", ¿̨u casi ceguera?:

Un día le regalamos entre todos un par de anteojos y le hicimos daño: comenzó a descubrir la realidad, primero con asombro, luego con una desazón de astrólogo convertido en agrimensor. "El mundo ha sido lindo", dijo. "Ahora me explico la otra poesía. ¿Vos sabías, por ejemplo, que las moscas tenían patas? [...]. Fue al campo y dijo que era un lugar atroz donde los pollos caminaban crudos [...]. "Anda, hermanito, a ver lo que pasa en el parque", me dijo una mañana, ensombrecido. Yo no encontré nada diferente, inusual. "Cómo que nada, dijo casi furioso, cómo que nada. ¿No viste que han derribado un árbol? El pobre tenía todavía vivas las hojas temblando al sol" (Adoum 2005, 185-86).

En este ensayo, busco explorar el modo cómo miran esos “ojos tristes", reconocer la potencia de esa mirada que percibe lo imperceptible para el ojo común, la delicadeza absoluta, lo minúsculo, el gesto casi invisible, la línea que dibuja una cordillera a lo lejos, el velo huidizo de las formas, la nitidez incorporal, el desnudamiento del aire, las hojas que aún tiemblan desasidas de su tierra. 


\section{Narrativa daviliana. \\ Mirar el paisaje, escuchar la vitalidad incorpórea, otear las esplendentes naderías}

"Visión y elogio del río Paute", clasificado como "prosa no ficcional" (en sus Obras completas, 1984, referida en la bibliografía), es un texto que clara y explícitamente se quiere elogio de paisaje. La fuerza descriptiva acoge un escenario geográfico que contiene el objeto de la atención narrativa: un río, el Paute. La mirada contemplativa del poeta narrador desciende desde una amplia meseta del altiplano hasta posarse en el fondo de un hondo valle: allí en donde lo que de súbito sucede es la irrupción de una perspectiva geográfica. El relato no tiene otro objetivo que narrar el paisaje como acontecimiento: su aparición, su recorte en el horizonte visual es un hecho en sí mismo, un acontecimiento que merece ser narrado no como antecedente de evento alguno, menos como soporte o escenario de una experiencia ajena al paisaje. La percepción del escenario, su registro visual y su relato dan cuenta de la experiencia de un espacio vivido. La narración no es sino el suceder del paisaje, la emergencia de las cosas que lo pueblan, el desnudamiento del aire, el declive del terreno, el despertar de una sonoridad, la percepción de alturas. En suma, el devenir imagen del espacio observado constituye dispositivo de escritura. Leamos: "Ahora el río y el camino se divorcian. De tarde en tarde, solamente el viento nos da noticia de la vida de las aguas; o se columbra una esquirla lejana por una grieta del monte. Una hora después sendero y río conciertan una cita. A la antigua belleza expansiva, ha sucedido la salvaje violencia de la fuerza. El viento encajonado materializa casi el alarido de la corriente ciega" (395). Solemos pensar que lo inefable pertenece al ámbito de lo extremadamente doloroso, al dominio de aquello que nos enmudece por acción de la violencia. En Dávila, hay una forma de lo inefable que también se ve atravesada por la violencia, pero de un modo radicalmente otro, uno que atiende al sutil movimiento de las fuerzas telúricas y de la vida en toda su potencia vital (una potencia hecha también de fuerza tanática): "En el primer momento, no se percibe sino la relumbre de una llamarada enceguecedora; un iracundo oleaje de viento centelleante. Sobreviene después un inefable desvanecimiento" (395).

El viento es un elemento nuclear en algunos de los más célebres cuentos de César Dávila, de hecho le da título a uno de ellos, "El viento". El relato narra la llegada del primer viento del verano, en la zona de un pequeño caserío ubicado en área rural. Sus personajes, un herrero y su joven esposa actúan y charlan en función del impacto que ejerce en la 
atmósfera familiar el desplazamiento de esa poderosa y vertiginosa masa de aire en movimiento. Más importante, la voz narrativa invierte la posición de los personajes en el relato: el elemento de la naturaleza atrapa su atención, mientras la efervescencia amorosa de la pareja recién casada parece obrar como contrapunto del desatado y febril desplazamiento de una corporalidad invisible: "[d]e todos los indicios del verano, el más corporal aunque invisible, era el viento. Su rosa de treinta y dos pétalos se desesperaba en la mitad del cielo. Y siendo incorpóreo, su perfil ondulaba sobre los cañaverales y en el fondo sucesivo de las mieses. Por las noches, oíasele gemir infantilmente en las rendijas de las ventanas y en los resquicios velludos de los encañizados" (240). Señala Gastón Bachelard, en El aire y los sueños, que la imagen del aire violento remite a la idea de la cólera pura, de la cólera sin objeto: "Con el aire violento podemos captar la furia elemental, la que es todo movimiento y nada más que movimiento" (280). Más adelante añade: "Es el silbido del viento lo que hace temblar al hombre que sueña, al hombre que escucha" (282). En el cuento, el primer diálogo de la pareja remite a la escucha del viento, una escucha que provoca sueños y también espanto:

—Anoche, mientas dormías, oí el primer viento del verano -dijo él, cuando la mujer apareció.

-Yo soñé que una nube de ángeles, pequeños como mosquitos, volaba sobre la casa, zumbando.

—Es el verano, tienes que cuidarte del viento (Dávila Andrade 1984, 240).

Observa el filósofo francés que la imaginación de las voces solo escucha las grandes voces. El viento llama la atención del narrador justamente a partir del impacto auditivo: el narrador no deja de escucharlo, como tampoco deja de oírlo la pareja. El viento gime, brama, silba: "Por la noche oíasele gemir infantilmente en las rendijas de las ventanas y en los resquicios velludos de los encañizados. Lanzaba las puertas como un chalán borracho. Bramaba entre los toros que ventean a sus hembras. Y hacía entrechocar las ringlas de herraduras recién labradas, produciendo la ilusión de un campanario de gnomos. Pero era entre los árboles en donde su rara sustancia adquiría el vértigo de la embriaguez" (240). Lo que seduce del cuento es la sutileza de la mirada y de la escucha narrativa: esa capacidad para advertir la fuerza vital en la materialidad minúscula, en el puro dinamismo del movimiento que altera todo lo que toca, en la vibración de la geografía, en la fuerza invisible que afecta a los cuerpos. En algún momento de la narración, mientras la herrerita baja por una carretera en busca de leche, llega el viento entre los flecos de una polvareda: se 
aproxima, toca, genera torbellinos de ropas y de gritos, arremete contra el cuerpo de la joven y, dice el texto, "la mostró desnuda desde la cintura". En el curso del encuentro, el desorden del sombrero despojado, las faldas revueltas, la jarra derrumbada, reconocemos casi un contagio de energía elemental, de fuerza erotizada. El herrero ha presenciado la escena, "bajaba corriendo, entre celoso y paternal. "Alcahuetería del viento..." (241). Luego del fragmento descrito, la pareja retorna a su habitación: se precipita el encadenamiento sucesivo de varias escenas que remiten a risas que conducen al encuentro amoroso.

\footnotetext{
En ese instante retornó el viento. Estaba enloquecido.

Dio vueltas a la casa buscando desesperadamente una grieta, un resquicio. Escaló los muros, hurgó entre las tejas, oyósele sollozar entre el encañizado de la techumbre. Finalmente, vino a forcejear la puerta del dormitorio, irguiéndose sobre las patas traseras como un perro. Por el ojo de la cerradura contempló a la pareja en su abrazo, y silbó con furia de ofidio, despertando bruscamente" (242).
}

Si inicialmente el viento gemía infantilmente, luego de su encuentro con la herrerita parece enloquecer. Dice Bachelard "Todas las fases del viento tiene su psicología. El viento se excita y se desanima" (284). En el cuento, el elemento aéreo no es sino puro vértigo, pura velocidad y embriagada fuerza que arremete, levanta y lanza cosas a su paso, hurga, gira, forcejea, desperdiga, espía, enfila. Las últimas líneas del relato no hacen sino seguir la enloquecida agitación del viento hasta alcanzar su destino final: enfurecido se busca la cola, se dispara a campo traviesa y enfila hacia el sur: "Llegó al borde del gran precipicio en cuyo fondo se adivina, como una hebra de estaño líquido, el río encañonado; y tornó a elevarse contrayendo convulsivamente sus pálidos anillos. Habiendo ganado la altura de los montes, abrió los brazos desnudos y gritó: ‘AAquilón, Aquilón, Padre Mío!". Luego, cerrando los bellos ojos color de humo se dejó caer en el abismo" (242). Lo que me interesa resaltar en Dávila Andrade es su cuidado trabajo con un lenguaje que procura dar forma a la materialidad intangible, al irreprimible furor de la materia. Más tarde, la herrerita regresa a su habitación tocada por el viento. Ella ha vuelto para cambiar su vestimenta y suplir el vestido por un pantalón. Pero la movilidad humana, de carácter funcional y práctico, deja de tener sentido ante el contacto con la materia aérea: "Acertó a hundir de una vez la pierna derecha; pero al intentar hacer lo mismo con la izquierda, cayó de espaldas riendo sobre la cama. El herrero que contemplaba la escena, dio media vuelta y aseguró la puerta con las aldabas" (242). Es el momento cuando el viento enloquece, silba con furia de ofidio y se despeña en el abismo con grito de cólera en 
celo. Si el grito es, como sugiere Bachelard, "la primera realidad verbal y la primera realidad cosmogónica" (281), la escritura de Dávila Andrade está hecha de la intensidad propia de la vida material, de pura tesitura auditiva, que tiene mucho de fundación cosmogónica, de sensorialidad primaria, de escucha absoluta, de imaginación material y dinámica, de las secretas y casi invisibles urdimbres de la vida.

Imposible no traer a la memoria "El cóndor ciego": la fuerza de ese viento en picada está hecha de la misma sustancia que provoca el último vuelo del Cóndor ciego. La mirada de Dávila parece mimetizarse o confundirse con la de los cóndores, en su capacidad para advertir el despertar de los gusanos, los excrementos que cubren el granito, la tensión de las alas y la curvatura del cuello de los mismos cóndores, las vibraciones del sol, las vetas de los ríos, la unión sudorosa de la tierra con el mar. Más aún, los ojos del narrador revelan lo que los cóndores miran: todos ocupan el mismo espacio, lugar de enunciación para uno y hábitat cotidiano de los animales. "Acrimonia" y "acuidad" son los sustantivos que elige Dávila para describir el cuerpo y la mirada del animal: "Inmovilizados en suntuosa acrimonia, miraban las inmensas almenas nevadas [...]. Es asombrosa la acuidad de su mirada. Desde inaccesibles oteros, o desde el aire -perdidos entre las nubes- clavan sus pupilas casi ígneas, en la lagartija friolenta que asoma un instante entre las grietas de las cercas; o sobre el conejo fatigado de vejez y correrías, que la muerte vapulea en el pajonal" (148). Cabe preguntarnos cómo acceden los ojos de Dávila a esos "inaccesibles oteros" desde donde ensaya una mirada que observa "minuciosamente la masa esplendente", distingue "las cristalizaciones columnarias; los finísimos canales neumáticos y las miríadas de naderías que forman la catedral helada" (148). Porque son las vibraciones de finísimas naderías las que activan las pupilas del narrador, quizás también casi tan ígneas como las de los cóndores de su narración. Mirada miope la del poeta, que convierte en objetos posibles de mirar y distinguir aquello que está cerca pero invisible, aquello que está dotado de una corporalidad hecha de vibraciones y efluvios que ponen en movimiento el espacio circundante. La caída vertiginosa de la escena final habla, otra vez Bachelard, de la "caída viva". Una que remite al sentido de la fuerza, del instante, del vértigo, de un "devenir fulminante: "El ciego ascendía serenamente, adivinando la inmensa candela de la tarde. Ya era una sola mancha horizontal en la ilimitada transparencia, sobre el mar. La sal húmeda y brillante de la profundidad le llegó al sentido. La aspiró con gusto mortal para el último gesto. Enseguida, sabiéndose ya sobre el abismo, cerró las alas de golpe" (150-51). Las líneas contienen la fuerza de una imagen excepcional que 
despliega a un mismo tiempo el destino de la altura y el de la profundidad.

\section{La pavorosa intimidad humana roza la visible superficie física}

"El semblante y la sangre" es un texto corto en el que Dávila ensaya una meditada reflexión acerca de la piel, como "ligero y plástico límite" que protege lo que denomina "el cálido país de la sangre". Cómo leer las emociones parece preguntarse Dávila. La sangre, observa, tiene la facultad de comunicar las íntimas latencias de su "orgánico subsuelo": sus movimientos y vibraciones imprimen una huella en el semblante: el rubor o la palidez informan a la mirada externa el estado de malestar o bienestar del cuerpo orgánico, sus desasosiegos y agitaciones. Escuchemos a Dávila Andrade: "Así, el cuerpo es el punto más externo de la pavorosa intimidad humana. Pero esta externidad está refluyendo incesante hacia su fuente, y lo recóndito se da, a veces inverecundo, a la mirada externa. Se interpenetran, vibran aunados en preciosa cópula y, siendo tan distintos, son una sola fuerza plástica dualizada por nuestra conciencia terrestre" (397). El semblante y la sangre conforman a la sensibilidad del escritor una sola fuerza, una que talla y despliega la subjetividad humana. En este sentido, las pasiones humanas encuentran sus propias formas de revelación, asequibles solamente al ojo capaz de advertir ese instante en el que las intensidades incorpóreas abren una visible materialidad. Ese es el ojo de Dávila, uno capaz de advertir lo que él mismo denomina "la misteriosa resonancia corporal", la ruta de lo impalpable en la superficie física, en la piel de la escritura podemos añadir. Imposible no reconocer que Dávila Andrade mira, escucha, escribe desde una radical certidumbre sensible, que se desnuda, se afecta, se transforma, se deshace ante la fuerza transformadora de la materia viva. Quiero pensar que esa mirada -aquella que justamente reconoce la pavorosa intimidad humana en las líneas del rictus- constituye la secreta potencia de la que están investidos los personajes davilianos en función de narradores. Personajes que observan de manera tangencial pero significativa, subrepticiamente, como desde un afuera que les provee de cierta ajenidad con relación al suceso relatado. Dávila describe así la secreta fuerza que labra el semblante: "A espaldas de nuestra somnolencia cotidiana, ella, la ardiente, la imaginífica, va labrando, aún a pesar nuestro, las líneas del rictus, el ceño y la sonrisa; el dulce guiño pasajero, la permanente mueca, el gesto involuntario. La devoradora enfermedad; las deformaciones bestiales; la repentina muerte, con su trampa recubierta de follaje tierno" (398). Mi apuesta es reconocer la activa presencia de "la ardiente, la imaginífica" en la constitución de algunos narradores. 
Quien narra "Vinatería del Pacífico" rememora un suceso vivido cuando era un joven de 18 años. $\mathrm{Al}$ inicio se presenta como alguien que vive en la calle, hambriento, abúlico, desorientado y soñoliento. Luego de un fortuito encuentro, reinicia su vida como ayudante en casa de una pareja de esposos, propietarios de la vinatería que da nombre al relato. La revelación del secreto trabajo nocturno, las misteriosas bondades del vino que secretamente buscan los clientes para devolver la vida a sus cuerpos, la disposición del negocio que encubre el único tonel en forma de gigantesco cubo en donde se zambullen los cuerpos, los enfermos, generan en el narrador un vago y creciente malestar. El joven ayudante interviene como testigo de ese extraño movimiento nocturno: obedece, observa desde la sombra, escucha los sonidos que producen los cuerpos aquejados al sumergirse paso a paso en el tonel, adivina e imagina el sentido de movimientos y ruidos. En el curso de la segunda y última noche acontece el accidente que precipita su huida: la sorpresiva muerte de una joven tomada por la tisis y la melancolía, mientras permanece zambullida en el líquido. La mirada y la persistente escucha del joven ayudante conducen la narración, su inexperta e ingenua sensibilidad dota de extrañeza al relato. Su mirada, tomada por el horror y la angustia, ofrece la clave para asimilar el desconcierto y ajenidad frente al atroz cúmulo de sucesos narrados: "Entramos. La mano derecha de la joven -férrea en su crispatura- tenía los dedos hincados al borde del tonel. Sus cabellos negros y luminosos flotaban en la tranquila superficie del vino, circuyendo el óvalo de la cara que miraba el tumbado" (27). Es la mirada que luego, tras la huida, reconoce en el anuncio que ávidamente busca en los periódicos, en los perdidos ojos del padre de la joven muerta en el tonel (a quien sigue y observa), índices probatorios de una extraña realidad acontecida. Es la mirada del narrador la que distingue en los rostros y gestos descritos esa secreta fuerza "ardiente", la "imaginífica". Esa que delinea la mano de la joven fallecida en el tonel, que labra los párpados rojos y perdidos del padre desolado, su paso lento y desvaído, en la imposible espera de la hija que ha fallecido en un tonel de vino.

Una disposición corporal semejante caracteriza al narrador de "Ataúd de cartón". Un vigilante, durante su relevo nocturno en un depósito de materiales, recibe y escucha una llamada telefónica que no le corresponde. Ese vigilante anónimo es el narrador del relato, puesto que le es revelada de manera azarosa y accidental el diálogo de una inconcebible confesión: "Alberto... hice lo que me indicaste. (Sollozó). Le maté esta mañana..., le ahogué con las cobijas... Ya me faltaba la leche: tengo secos los senos... era una carga para ambos... (Nuevo sollozo)" 
(38). El narrador vigilante escucha, llega al parque en donde se han citado Alberto y la joven madre filicida; examina, fantasea, mira desde afuera el desarrollo de una situación ajena. La conveniente distancia en donde se coloca, le permite seguir los pasos de Alberto, espiarlo y comunicar en su narración el horror de un sórdido acto de violencia: las caricias públicas del hombre, la cobarde puñalada a la mujer mientras la abraza, las manos que abandonan la caja de cartón entre los escombros del arrabal urbano, el retorno del asesino al lugar del crimen, la historia que inauditamente declara el hombre de la caja a la concurrencia de una ínfima taberna: "Una noche cogí a una; pero estaba sola. No pecaba Me dijo que no tenía cama. Dormía sobre el serrín. Le oprimí la garganta y se asustó mucho. Le metí un pañuelo en la boca y la hice mía. Era virgen. Tuvimos un hijo. El chico murió esta mañana; y ella, esta tarde. Y yo aquí, bebiendo, a ver qué pasa... [...] y no pasa nada... ¡Nada!” (42). La perturbación que genera en la lectura ese no pasar nada es efecto de la posición que asume el narrador: una impúdica intromisión lo hace partícipe del inaudito horror que de pronto sobreviene impune: infanticidio y feminicidio sin posibilidad de justicia alguna.

"La batalla" es un cuento que me sorprende de manera especial, por esa capacidad de Dávila en crear una voz narrativa capaz de dar cuenta desde una situación inaudita en su ruindad, extrañeza y pasmoso absurdo, sin descuidar al mismo tiempo la sorprendente ternura que puede caber en situación semejante. En el cuento mencionado, asistimos a la agonía de una porquera, en presencia de su marido (ruin y vividor) y sus dos hijos. En un ambiente de pobreza, suciedad, malos olores, moscas, descomposición del cuerpo agonizante, el marido, tras intentar violar a la hija adolescente - “'por qué se quejaba con aquella dulce y sinuosa debilidad? ¿Necesitaría, tal vez, desde el fondo de su dolor y, sin saberlo, un par de manos de hombre?" (18)-, abandona el cadáver y a los pequeños, tras robar a su mujer el dinero y unos pocos objetos de valor. En un escenario de fogonazos y guerra civil en las calles, el hijo también abandona la casa. Se queda sola la hija con la madre amortajada, que envuelta en sábanas luce como una gran muñeca de trapo. La descripción de esa imagen, la hija abrazada al cadáver de su madre, resulta de una delicadeza poética infinita:

Aguedita y la blanca muñeca de trapo formaban un solo bulto y vivían entrefundidas como únicamente les es posible a las mujeres, sin incomodarse, mezcladas, copuladas, sintiéndose, amándose, una dentro de otra, dos cuerpos en uno solo, y una sola mujer las dos. El [el hijo], en cambio, estaba abandonado. Las mujeres, las hermanas, las madres, se acompañaban entre sí, ocupando al mismo tiempo el mismo sitio, dulce y tranquilo (26). 
¿Quién es el narrador del cuento? Inicialmente, parece adoptar una mirada en buena medida realista en su esfuerzo por dar cuenta de los disparos en la ciudad, la descripción del escenario doméstico alrededor de la moribunda: destaca la ubicación de la tienda/casa de la porquera, las dinámicas cotidianas del trabajo que ocupa a la familia, relata con detenimiento los pensamientos íntimos del marido y, sobre todo, la lenta descomposición del cuerpo en agonía. La narración no escatima la detallada relación de sonidos, líquidos, piojos y pulgas que salen del cuerpo en su lenta descomposición, así como el minucioso seguimiento a la llegada de las moscas en la escena tras la "cadaverina sustanciosa y fresca". Lo que prima en el relato es la desnuda, así como grotesca y tremebunda, exposición del cuerpo tomado por la muerte, como también los pensamientos zafios y degradantes del hombre-padrastro-puerco en su escandaloso menosprecio por la muerta. Ese mismo narrador, de manera súbita, da un giro radical en la sintaxis y tesitura del relato: la escritura abandona el tono realista para dar paso a imágenes plenamente poéticas: entonces prima la actitud de ternura al descubrir, observar y describir la abarcadora imagen de la muchacha abrazada a su madre muerta:

\begin{abstract}
Ahora sí dormiría, dormiría suavemente al lado de la bella y blanca muñeca dormida, y juntas, se alejarían por el horizonte hacia la inmensidad de Dios. Huirían para siempre de los hombres, de todos los hombres del mundo y especialmente del hombre-animal-padrastro y del hombre-animal-hermano y de los puercos, cuyos cuerpos veía confundidos y refundidos en uno solo, huyendo por la montaña, y escondiéndose del Amor entre las grietas tapizadas de fango y de cochambre. Así huían los dos cobardes animales embutidos en un solo cuerpo bestial [... (27). ${ }^{2}$
\end{abstract}

Allí está la clave en la mirada de César Dávila: una que no escatima detenerse en los arrebatos de la muerte, sin desatender con extremada sutiliza la sorprendente ternura que puede borbotar entre los resquicios de la vida, aun en situación de inimaginable sordidez y desesperanza. Esa

2. La imagen de los "hombres-animales-puercos" concentra un disparador de sentidos que permite volver sobre algunos de los cuentos anteriores: el vinatero-oso mata frente a los ojos del narrador a Laurel, su perro, para que no pueda desenterrar el cadáver de la joven tísica, depositada en el jardín de la vinatería. La fortaleza del vinatero -"Luego comencé a engordar y ya me ves: un oso. (Aquí río jovialmente). Hice dinero con las fuerzas adquiridas y puse este negocio" ("Vinatería del Pacífico", 24) - contrasta singularmente con la fragilidad de la muchacha que muere en el tonel -"Sus anchos ojos oscuros se volvieron lineales y en su fondo pude ver, por un instante, un luminoso abismo de la más pura melancolía" ("Vinatería del Pacífico", 26)-, así como con la desorientada figura del anciano que espera la milagrosa aparición de su hija. Similar situación es posible notar en "Ataúd de cartón", quien ha cometido el acto de feminicidio, regresa luego al lugar del crimen. Así describe la escena el narrador: "Reconocí fácilmente el punto exacto. El hombre se aproximó a él, y se puso en cuclillas al borde de la mancha oscura fundiéndose poco a poco con ésta y con la sombra rodeante. Creí escuchar un sollozo. Luego, un murmullo y, por fin, el ritmo de una respiración ardorosa batiendo sobre la huella. Aspiraba como un toro apasionado el 
radical ambivalencia de la que está cargada su mirada es posible reconocerla en el gesto suicida. El vertiginoso descenso del Viento en el fondo del precipicio, la audaz y decidida caída del cóndor ciego en el abismo, están hechas de la misma fibra que el suicido del poeta Dávila Andrade. Quiero valerme de una reflexión de Walter Benjamin a propósito del suicidio en el contexto de la vida moderna: "Lo moderno tiene que estar en el signo del suicidio, sello de una voluntad heroica que no concede nada a la actitud que les es hostil. Ese suicido no es renuncia sino pasión heroica” (93). Imposible no dejarnos seducir por el contagio de esa potente constitución heroica que vertebra la vida y escritura de César Dávila Andrade. Vale tal vez cerrar esta reflexión con un retrato, cargado de afecto y admiración, que le dedica su amigo, el poeta venezolano Juan Liscano, a los pocos días de su muerte:

Lo que más convencía en César Dávila Andrade era su empecinada voluntad en perseguir un conocimiento que al mismo tiempo le iluminaba y le cegaba [...]. Esa exploración desordenada de sí mismo consumió por entero su energía de convivir y de resistir. En vez de liberarse mediante la obra, la padeció, se hundió en el sufrimiento múltiple, hecho de vuelos y de caídas, de florecimientos y terribles sequías. Además estaba solo. Además periódicamente bebía [...].

Y en verdad, en Dávila Andrade combatían sin cesar ese empeño de reintegración y de oscuros impulsos de desintegración; ese conocimiento intelectual de las posibilidades mentales y espirituales del hombre y el tremendo asco de una rebeldía casi ancestral, de una melancolía andina, quechua, de una voluntad indígena de novivir $[\ldots]$

Su gran Obra se cumplió en el lenguaje. Su lenguaje es nuevo, es propio, es único. Para crear un lenguaje propio y nuevo, se requiere sentir algo nuevo y propio. Destruir y negar es fácil. Construir y afirmar resulta extremadamente difícil. Al precio de su propia vida, César Dávila Andrade, inspirado por las visiones de trascendencia que poblaban su alma y su mente, logró crear un ámbito de poesía, de ficción literaria tan singulares como sugestivos, tan reales como mágicos (Liscano 1967, 4,5).

olor de la sangre de la hembra" ("Atadúd de cartón", 41). La descripción contrasta notablemente con la imagen que de la joven madre asesinada preservamos del cuento: la primera aparición de María Luisa en el parque: "La identifiqué al instante por la caja de cartón que sostenía en sus rodillas" (38), ese halo de abandono cobra fuerza con el relato que su mismo asesino hace en la taberna, citado líneas arriba.

Este devenir hombre-toro, hombres-puercos, ha sido reinventado de manera creativa en la propuesta visual de las adaptaciones gráficas que propone editorial El Fakir. Así lo destaca Yanna Hadatty en su ensayo "Releer al Fakir a 100 años, palabra e imagen", que hace parte de la misma colección: "en la adaptación gráfica la historia tiene que ver más con el feminicidio en interacción con la ciudad mientras en el cuento de Dávila Andrade a la mitad ocurre el asesinato de María Luisa por parte de Alberto. Indudablemente la construcción central se debe a la imagen del hombre-toro" (Hadatty, 2018, 6). A propósito de la adaptación gráfica de "La batalla", continúa Hadatty, "Otra vez el paralelismo funciona a partir de la imagen hum/animal, potenciada por el dibujo de los cerdos de la página 14 donde hermano y padrastro pueden distinguirse por bigotes, peinado o gorra al interior de la piara, y la denominación textual que se mantiene para ambos: 'hombre-animal-padrastro,' 'hombre-animal-hermano'” (Hadatty, 6). 


\section{Bibliografía}

Adoum, Jorge Enrique. 1986. Entre Marx y una mujer desnuda. Quito: El Conejo.

—. 2005. "César Dávila Andrade el faquir". En Edgar Freire, compilador. Parias, perdedores y otros antihéroes. Quito y sus célebres personajes populares. Quito: Trama. 183-186.

Bachelard, Gaston. 2017. "El viento". En El aire y los sueños. Ensayo sobre la imaginación del movimiento [1958]. México: Fondo de Cultura Económica, 278-293.

Benjamin, Walter. 1991. "Lo moderno". En Poesía y capitalismo. Iluminaciones II, prólogo y traducción de Jesús Aguirre. Madrid: Taurus. 85-120.

Dávila Andrade, César. 1984. “Ataúd de cartón” [37-43], "El cóndor ciego" [147-150],

"El semblante y la sangre" [397-399], "Teoría del titán contemplativo. Ensayo sobre la poesía de Jorge Carrera Andrade" [423-426], "El viento" [239-242], "Visión y elogio del río Paute" [395-396], "Vinatería del Pacífico" [21-28]. En Obras completas. Relato, t. II. Cuenca: Pontificia Universidad Católica del Ecuador, Sede Cuenca / Banco Central del Ecuador.

—. 2018. "La batalla”. En Cuentos. Quito: El Fakir. 13-28.

Cárdenas, Eliécer. 2008. El pinar de Segismundo. Quito: Ministerio de Cultura.

Dávila Vázquez, Jorge. 2005. “El faquir. César Dávila Andrade y la ciudad". En Edgar Freire, compilador. Parias, perdedores y otros antibéroes. Quito y sus célebres personajes populares. Quito: Trama. 193-199.

Hadatty, Yanna. 2018. "Releer al fakir a 100 años, palabra e imagen". En Ensayo. Quito: el fakir. 1-10.

Liscano, Juan. 1967. "El solitario de la gran obra". En Zona franca. Caracas, año III, no. 45 , mayo. 4-7.

Salazar, Gustavo, editor. 2012. César Dávila Andrade. El Fakir. Serie Cuadernos "A pie de página" No. 5. Madrid: s/e.

Vintimilla, María Augusta. 2012. "César Dávila Andrade: el resplandor del abismo”. En Revista Pucara. Cuenca, No. 24. 215-250. 